\title{
KREATIVITAS MAHASISWA PADA MATA KULIAH TATA RIAS FOTO/TV/FILM DAN KARAKTER DI JURUSAN TATA RIAS DAN KECANTIKAN
}

\author{
Indah Melia Gusrita. K
}

Program Studi Pendidikan Tata Rias dan Kecantikan, Fakultas Pariwisata dan Perhotelan, Universitas Negeri Padang email : indahmelia01@yahoo.com

\author{
Rahmiati \\ Program Studi Pendidikan Tata Rias dan Kecantikan, Fakultas Pariwisata dan Perhotelan, Universitas Negeri Padang \\ email : rahmiati19@yahoo.com
}

Abstract- This research background is the importance of creativity in learning MakeUp Characters in order to produce extraordinary works based on the character of the character who wants to appear. The purpose of this research was to find out student creativity when viewed from the creative person in learning MakeUp Characters in make up and beauty department in terms of fluency, flexibility and authenticity. This research is descriptive research with quantitative approach. The research population was students majoring in make upy and Beauty class 2016 sessions $A$ and $B$. The sampling technique is done by total sampling technique. The data analysis technique is done by determining the frequency distribution and determining the level of achievement of respondents, then categorizing the creative person through the value of the respondents' achievement based on the value classification. The results of the data show that the average student creativity in make-up learning characters in terms of fluency is 49.38 with the most categories at the moderate level of 26 people (59.1\%). Dexterity average is 47.02 with the most category at the moderate level, which is 20 people (45.5\%). The average authenticity is 46.11 with the most categories at a good level of 20 people (45.5\%).

Keywords : Creativity, Character Make Up, Fluency, Flexibility, Originality

\section{PENDAHULUAN}

Tujuan Pendidikan Nasional menurut UU No. 20 tahun 2003 adalah mengembangkan potensi peserta didik agar menjadi manusia yang beriman dan bertakwa kepada Tuhan YME, berakhlak mulia, sehat, berilmu, cakap, kreatif, mandiri dan menjadi warga negara yang demokratis dan bertanggung jawab. Universitas Negeri Padang sebagai salah satu lembaga pendidikan yang menyiapkan calon pendidik harus mampu menghasilkan tenaga pendidik yang professional dibidangnya. Hal tersebut sesuai dengan fungsi Universitas Negeri Padang yaitu menyelenggarakan pendidikan tinggi, penelitian, dan pengabdian masyarakat. Pendidikan merupakan lembaga yang penting bagi proses penyiapan dan peningkatan kualitas sumber daya mahasiswa agar benar-benar berkualitas serta mempunyai keunggulan kompetitif sehingga mampu bersaing dalam situasi dunia yang semakin menglobal.

Make Up karakter merupakan salah satu pokok bahasan yang dibahas pada mata kuliah Tata Rias Foto/Tv/Film dan Karakter berdasarkan kurikulum pendidikan pada jurusan Tata Rias dan Kecantikan. Make up karakter adalah suatu tata rias yang di terapkan untuk mengubah penampilan seseorang dalam hal umur, sifat, wajah, suku, dan bangsa 
sehingga sesuai dengan tokoh yang diperankan, (Halim, 2013:11). Menurut Thowok (2012:12), "rias wajah karakter membantu para pameran berakting, dengan membuat wajahnya menyerupai watak yang akan dimainkan".

Make Up karakter merupakan suatu tata rias yang digunakan untuk merubah penampilan seseorang sesuai dengan tokoh yang diperankan untuk keperluan berakting, yang berarti rias wajah karakter membantu para pameran berakting, dengan membuat wajahnya menyerupai watak yang akan dimainkan dalam sebuah pertunjukan. Dalam artian desain, warna, pakaian dan ornamen harus mendukung untuk mengoptimalkan rias wajah. Merujuk pada pendapat Kusantati dalam Alhekmah (2014) , "Tata rias wajah karakter merupakan suatu seni menggunakan bahan-bahan kosmetika untuk mewujudkan suatu peran atau karakter dengan memperhatikan pencahayaan (lighting) dan titik pandang penonton". Agar bisa dilihat dari titik pandang penonton, warna-warna yang digunakan pada make up karakter harus bisa mewujudkan karakter yang diciptakan.

4 unsur make up karakter tersebut yaitu:

1. Desain. Menurut Yuliati (2007) "Desain adalah suatu rancangan yang disusun berdasarkan garis, bentuk, warna, ukuran, dan tekstur menjadi satu kesatuan, sehingga menghasilkan sesuatu yang indah dan menarik".

2. Warna. Menurut Ernawati dalam Irnis Uchi (2018) mengatakan bahwa, "Warna merupakan unsur desain yang paling menonjol yang dapat mengungkapkan suasana perasaan atau watak benda yang dirancang".

3. Pakaian. Setelah menciptakan suatu karya make up karakter, agar lebih terlihat lebih mempunyai kemiripan dengan objek yang diinginkan tidak ketinggalan pemakian atau penyiapan pakaian yang sesuai dengan karakter

4. Ornamen. Ornamen adalah benda pelengkap, tapi memiliki fungsi penting dalam sebuah karya make up.

Capaian pembelajaran pada pokok bahasan make up karakter pada mata kuliah Tata Rias Foto/Tv/Film dan Karakter adalah: 1) Menguasai pengetahuan tentang rias wajah karakter dan dapat membuat desain rias wajah karakter sesuai dengan tema; 2) Mampu melakukan rias wajah karakter sesuai tema, prosedur kerja dan keselamatan kerja. (silabus mata kuliah Tata Rias Foto/Tv/Film dan Karakter periode Januari - Juni 2018).

Penyediaan pokok bahasan Make Up Karakter memberikan peluang bagi mahasiswa untuk mengembangkan bakat dan keterampilan dalam menciptakan suatu riasan yang lebih menonjolkan terhadap peniruan suatu watak atau tokoh. Untuk setiap karakter dapat dilakukan rias wajah yang menonjolkan secara realistis maupun non realistis. Secara realistis misalnya make up efek luka pada wajah, dimana kulit wajah tanpak seperti sobek dan berdarah. Sedangkan non realistis kita temukan pada Make Up fantasy berupa bentuk imajinatif, (Thowok, 2012:12).

Permasalahan yang banyak ditemukan pada mahasiswa dalam pembelajaran make up karakter diantara mereka yang merasa kurang ide-ide untuk menciptakan karakter-karakter yang di inginkan pada saat melakukan pembelajaran praktik. Hal ini dikarenakan mahasiswa kurang percaya diri dan beranggapan tidak memiliki kreativitas. Di samping itu kurangnya kreativitas mahasiswa juga di sebabkan karena tidak memiliki keinginan sendiri untuk membentuk karakter baru hanya membuat ulang bentuk-bentuk karakter yang lama, tidak adanya pembaharuan dalam desain make up karakter yang diciptakan.

Selain dari permasalahan di atas ada juga mahasiswa beranggapan untuk menciptakan make up yang bagus berasal dari kemiripan dengan karakter telah ada seperti yang bisa di dapatkan dengan melihat berbagai sumber seperti youtube dan google, sehingga mahasiswa kurang tertarik untuk memunculkan pembaharuan dengan karakter tersebut. Mahasiswa merasa puas dengan hasil make up yang seadanya, dan merasa cukup dengan nilai yang di dapat. Dalam melihat bentuk desain make up yang ingin diciptakan mahasiswa cenderung menirukan persis dengan sumber yang di dapat dengan harapan mendapat nilai yang memuaskan dari dosen karena desain make up yang dicontoh sudah bagus, di bandingkan dengan membuat desain baru berdasarkan contoh yang sudah ada karena akan berkemungkinan gagal dan mendapat nilai yang kurang memuaskan dari dosen. Mahasiswa juga kurang memiliki ide-ide alternatif jika mengalami kendala dalam pengaplikasian make up karakter. Dari sekian 
banyak permasalahan yang paling terlihat dapat disimpulkan bahwa kreativitas mahasiswa kurang.

Masalah - masalah yang ada mengacu pada pribadi yang kreatif karena pribadi yang kreatif akan menghasilkan produk yang kreatif berupa make up karakter yang bagus.

Kreativitas memang sangat dibutuhkan di dalam masyarakat dan dunia kerja maupun dalam pembelajaran. Dalam mengaplikasikan make up karakter yang membutuhkan sumber daya manusia berkualitas tentu saja kreativitas sangat dibutuhkan. Bayangkan saja jika mahasiswa ingin menciptakan sebuah Make Up Karakter tidak memiliki ide yang inovatif !, hasil sebuah karya tidak akan ada pembaharuan dan akan terlihat monoton pada sebuah bentuk tertentu. Inovatif merupakan bagian dari sebuah kreativitas. Di dunia make up yang begitu cepat berubah dan berivonasi, kreativitas menjadi penentu keunggulan. "Lingkungan yang berubah secara cepat dengan elemen yang kompleks dan beragam memerlukan respons yang fleksibel dan inovatif, solusi kreatif dapat memberi fleksibilitas untuk mengatasi masalah serta beradaptasi" (Artur, 2011:6-7). Daya kompetitif mahasiswa sangat ditentukan pula oleh kreativitas sumber dayanya.

Menurut Sudarma Momon (2013:25) menyatakan bahwa, kreativitas lahir dalam bentuk kombinasi. Orang kreatif adalah mengombinasikan bahan-bahan dasar yang sudah ada, baik itu ide, gagasan atau produk, sehingga kemudian melahirkan hal yang baru (novelty). Pada dasarnya kreativitas berasal dari kata to Create yang artinya membuat. Kreatif dan kreativitas memiliki konsep dan hakikat yang sama serta saling berkaitan. Menurut Solso Dkk. (2008:444), "Kreatifitas adalah suatu aktivitas kognitif yang menghasilkan suatu pandangan yang baru mengenai suatu bentuk permasalahan dan tidak dibatasi pada hasil yang pragmatis (selalu dipandang menurut kegunaannya)".

Dapat disimpulkan, bahwa kreativitas merupakan kombinasi dari ide yang sudah ada menjadi ide-ide baru yang lebih inovatif, menciptakan pengembangan produk baru yang berdasarkan pada ide yang telah ada sebelumnya. Seperti halnya mahasiswa menerapkan pada pembelajaran make up karakter, untuk bisa mengikuti alur modern yang semakin berkembang maka make up karakter mahasiswa juga harus lebih inovatif menjadi ide-ide baru untuk menciptakan pengembangan berdasarkan ide-ide yang sudah muncul sebelumnya. Pribadi (person) merupakan tindakan kreatif muncul dari keunikan keseluruhan kepribadian dalam interaksi dengan lingkungannya (Hulbeck, dalam Munandar, 2004).

Prilaku kreatif memberi pengaruh yang khas dan unik dari keseluruhan kepribadian individu terhadap lingkungan. Dari pribadi khas dan unik, seorang individu (peserta didik) diharapkan dapat menimbulkan ide-ide baru dan produk-produk yang inovatif, (Lusiana, 2013). Selanjutnya Munandar (1992:47) mengatakan, "Prilaku kreatif adalah hasil dari pemikiran kreatif'. Pribadi yang kreatif merupakan ungkapan eksperi diri seorang individu dari keunikan dengan lingkungannya yang mana setiap individu yang kreatif memiliki intelegensi, pemikiran kognitif/intelektual, serta berfikir sintesis yang mana kemampuan untuk melihat hubungan yang tidak mampu orang lain untuk melihatnya, (Irnis,2018).

Untuk menciptakan make up karakter sesuai dengan tokoh yang akan diperankan sangat membutuhkan kreativitas dari mahasiswa. Kreativitas dapat mengembangkan bentuk inovasi baru dari make up karakter yang sudah ada sehingga bentuk dari make up karakter tidak monoton. Kreativitas akan menghasilkan ide-ide dan penemuan yang baru, yang berkaitan dengan keterampilan mahasiswa untuk mengubah ide yang telah ada menjadi sesuatu yang baru, mahasiswa yang kreatif dapat dikatakan memiliki pribadi yang kreatif.

Pribadi kreatif mahasiswa dapat dilihat dari pola pikirnya, Olson (1992:11) mengatakan bahwa Kreativitas terdiri dari 2 unsur yaitu pertama Kefasihan, yang ditunjukan oleh kemampuan menghasilkan sejumlah gagasan pemecahan masalah secara lancar dan cepat. kedua Keluwesan, yang pada umumnya mengacu pada kemampuan untuk menemukan gagasan yang berbeda-beda dan luar biasa untuk memecahkan suatu masalah. Menurut Evans, (1994:49) banyak karakteristik individual yang ditemukan untuk mendukung perilaku kreatif, diantaranya: 1) Kesadaran dan sensitivitas terhadap problem; 2) Ingatan; 3) Kelancaran; 4) Fleksibilitas; 5) Keaslian; 6) Disiplin dan keteguhan diri; 7) Kemampuan adaptasi; 8) "permainan" intelektual; 9) Humor; 10) Nonkonformitas; 11) Toleran terhadap 
ambiguitas; 12) Kepercayaan diri; 13) Skeptisime;14) Inteligensi. Sedangkan menurut Munandar (2009) mengatakan bahwa kretivitas berhubungan dengan antara lain: 1) Fluency, yaitu kesigapan, kelancaran, untuk menghasilkan banyak gagasan secara cepat, 2) Flexibility, yaitu kemampuan untuk menggunakan bermacammacam cara dalam mengatasi masalah, 3) Originality, yaitu kemampuan untuk mencetuskan gagasan unik atau asli, 4) Elaborasi, adalah kemampuan untuk melakukan hal yang datail dari suatu objek.

Melihat dari banyaknya indikator pribadi kreatif yang disebutkan para ahli dalam pribadi kreatif, peneliti menetapkan dalam penelitian ini memakai 3 indikator pribadi kreatif yaitu fluency, flexibility, dan originality.

1. Fluency, yaitu kesigapan, kelancaran, untuk menghasilkan banyak gagasan secara cepat. Kelancaran dalam menciptakan karakter yang ingin dibuat sesuai tema. Didukung oleh pendapat Olson Robert (1992:11) yang menyatakan bahwa "Kefasihan ditunjukan oleh kemampuan menghasilkan sejumlah besar gagasan pemecahan masalah secara lancar dan tepat".

2. Flexibility, yaitu kemampuan untuk menggunakan bermacam-macam cara dalam mengatasi masalah, kemampuan untuk memproduksi sejumlah ide, jawabanjawaban atau pertanyaan-pertanyaan yang bervariasi, dapat melihat suatu masalah dari sudut pandang yang berbeda, mencari alternatif atau arah yang berbeda-beda, serta mampu mnggunakan bermacam-macam pendekatan atau cara pemikiran. Orang yang kreatif adalah orang yang luwes dalam berpikir. Menurut pendapat Olson Robert (1992:11), “Keluwesan pada umumnya mengacu pada kemampuan untuk menemukan gagasan yang berbeda-beda dan luar biasa untuk memecahkan suatu masalah".

3. Originality, yaitu kemampuan untuk mencetuskan gagasan unik atau asli. Keaslian juga terkait dengan seberapa jarang suatu ide dihasilkan. Menurut Evans (1994:53), "keaslian merupakan kemampuan untuk menghasilkan ide-ide luar biasa, memecahkan problem dalam cara luar biasa atau menggunakan hal-hal atau situasi dalam cara yang luar biasa".

Berdasarkan permasalahan di atas maka peneliti ingin melakukan penelitian kepada mahasiswa jurusan Tata Rias dan Kecantikan dengan judul "Kreativitas Mahasiswa pada Mata Kuliah Tata Rias Foto/Tv/Film dan Karakter Di Jurusan Tata Rias dan Kecantikan".

Tujuan penelitian ini adalah untuk megetahui Kreativitas mahasiswa jika dilihat dari pribadi kreatif dalam pembelajaran Make Up Karakter di jurusan tata rias dan kecantikan yang ditinjau dari kelancaran, keluwesan dan keaslian.

\section{METODE}

Penelitian ini adalah penelitian deskriptif dengan pendekatan kuantitatif. Penelitian ini dilaksanakan jurusan Tata Rias Dan Kecantikan fakultas Pariwisata dan Perhotelan Universitas Negeri Padang. Penelitian ini dilakukan setelah terlaksananya seminar proposal.

Pada penelitian ini, populasi yang dimaksudkan adalah seluruh mahasiswa jurusan Tata Rias dan Kecantikan angkatan 2016 yang terdaftar pada kelas sesi A dan B yang berjumlah 44 orang. Sampel yang digunakan yaitu sebanyak 44 orang sesuai dengan banyak populasi.

Jenis data yang digunakan terdiri dari data primer dan data sekunder. Dengan teknik pengumpulan data menggunakan kuosioner atau angket dan dokumentasi. Instrumen yang digunakan yaitu rubrik penilaian dengan skala likert. Selanjutnya melakukan uji instrumen yang terdiri dari uji validitas dan realiabilitas. Terakhir melakukan analisis data dengan menentukan distribusi frekuensi, menentukan tingkat pencapaian responden dan pengkategorian pribadi kreatif menggunakan klasifikasi penilaian.

\section{HASIL DAN PEMBAHASAN}

A. Hasil

1. Pribadi Kreatif Mahasiswa Yang Dilihat Dari Fluency Pada Pembelajaran Make Up Karakter

Hasil analisis menggambarkan nilai rata-rata Kelancaran (Fluency) pada pembelajaran Make Up Karakter adalah 
49.38 dengan standar deviasi \pm 6.97 , nilai minimum 31 dan maksimum 59.

Tabel 1. Distribusi Frekuensi Pribadi Kreatif Mahasiswa Yang Dilihat Dari Fluency Pada Pembelajaran Make Up Karakter

\begin{tabular}{|c|c|c|c|}
\hline $\begin{array}{c}\text { Interval } \\
\text { Presentae }\end{array}$ & Kategori & $\begin{array}{c}\text { Frekuensi } \\
\text { (f) }\end{array}$ & $\begin{array}{c}\text { Presentase } \\
(\%)\end{array}$ \\
\hline $\begin{array}{c}90 \%- \\
100 \%\end{array}$ & $\begin{array}{c}\text { Sangat } \\
\text { Baik }\end{array}$ & 0 & 0.0 \\
\hline $80 \%-89 \%$ & Baik & 9 & 20.5 \\
\hline $65 \%-79 \%$ & Sedang & 26 & 59.1 \\
\hline $55 \%-64 \%$ & Kurang & 6 & 13.6 \\
\hline $0 \%-54 \%$ & $\begin{array}{c}\text { Kurang } \\
\text { Sekali }\end{array}$ & 3 & 6.8 \\
\hline Jumlah & & 44 & 100 \\
\hline
\end{tabular}

Tabel 1 menunjukkan bahwa distribusi frekuensi kelancaran dalam melakukan make up karakter dari 44 orang sampel ditemukan sebanyak 9 orang $(20.5 \%)$ mahasiswa berada pada kategori baik, 26 orang $(59.1 \%)$ mahasiswa berada pada kategori sedang, 6 orang (13.6\%) mahasiswa berada pada kategori kurang dan 3 orang $(6.8 \%)$ mahasiswa berada pada kategori kurang sekali.

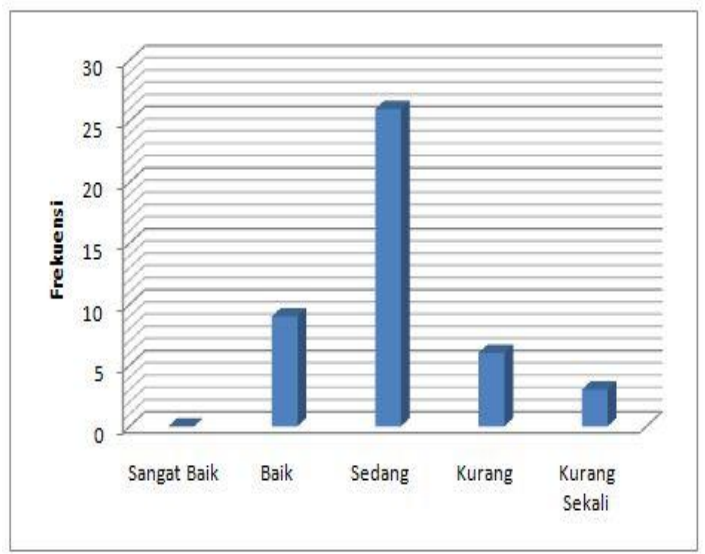

Gambar 1: Grafik Pribadi Kreatif Mahasiswa Yang Dilihat Dari Fluency Pada Pembelajaran Make Up Karakter
2. Pribadi Kreatif Mahasiswa Yang Dilihat Dari Keluwesan (Flexibility) Pada Pembelajaran Make Up Karakters

Hasil analisis menggambarkan nilai rata-rata Keluwesan (Flexibility) mahasiswa pada pembelajaran Make Up Karakter adalah 47.02 dengan standar deviasi \pm 4.464 , nilai minimum 38 dan maksimum 56.

Tabel 2. Distribusi Frekuensi Pribadi Kreatif Mahasiswa Yang Dilihat Dari Keluwesan (Flexibility) Pada Pembelajaran Make Up Karakter

\begin{tabular}{|c|c|c|c|}
\hline $\begin{array}{c}\text { Interval } \\
\text { Presentae }\end{array}$ & Kategori & $\begin{array}{l}\text { Frekuensi } \\
\text { (f) }\end{array}$ & $\begin{array}{c}\text { Presentase } \\
(\%)\end{array}$ \\
\hline $\begin{array}{l}90 \%- \\
100 \%\end{array}$ & $\begin{array}{c}\text { Sangat } \\
\text { Baik }\end{array}$ & 3 & 6.8 \\
\hline $\begin{array}{l}80 \%- \\
89 \%\end{array}$ & Baik & 18 & 40.9 \\
\hline $\begin{array}{l}65 \%- \\
79 \%\end{array}$ & Sedang & 20 & 45.5 \\
\hline $\begin{array}{c}55 \%- \\
64 \%\end{array}$ & Kurang & 3 & 6.8 \\
\hline $0 \%-54 \%$ & $\begin{array}{c}\text { Kurang } \\
\text { Sekali }\end{array}$ & 0 & 0.0 \\
\hline Jumlah & & 44 & 100 \\
\hline
\end{tabular}

Tabel 2 menunjukkan bahwa distribusi frekuensi keluwesan dalam melakukan make up karakter dari 44 orang sampel ditemukan sebanyak 3 orang $(6.8 \%)$ mahasiswa berada pada kategori sangat baik, 18 orang $(40.9 \%)$ mahasiswa berada pada kategori baik, 20 orang $(45.5 \%)$ mahasiswa berada pada kategori sedang dan 3 orang $(6.8 \%)$ mahasiswa berada pada kategori kurang. 


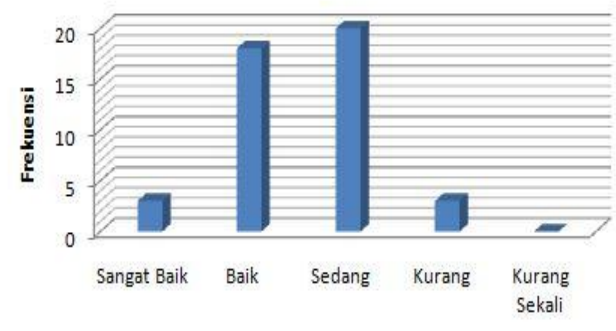

Gambar 2: Grafik Pribadi Kreatif Mahasiswa Yang Dilihat Dari Flexibility Pada Pembelajaran Make Up Karakter

3. Pribadi Kreatif Mahasiswa Yang Dilihat Dari Keaslian (Originality) Pada Pembelajaran Make Up Karakters

Hasil analisis menggambarkan nilai rata-rata Keaslian (Originality) mahasiswa pada pembelajaran Make Up Karakter adalah 46.11 dengan standar deviasi \pm 7.182, nilai minimum 25 dan maksimum 52.

Tabel 3. Distribusi Frekuensi Pribadi Kreatif Mahasiswa Yang Dilihat Dari Keaslian (Originality) Pada Pembelajaran Make Up Karakter.

\begin{tabular}{|c|c|c|c|}
\hline $\begin{array}{c}\text { Interval } \\
\text { Presentae }\end{array}$ & Kategori & $\begin{array}{c}\text { Frekuensi } \\
(\mathrm{f})\end{array}$ & $\begin{array}{c}\text { Presentase } \\
(\%)\end{array}$ \\
\hline $\begin{array}{c}90 \%- \\
100 \%\end{array}$ & $\begin{array}{c}\text { Sangat } \\
\text { Baik }\end{array}$ & 0 & 0.0 \\
\hline $\begin{array}{c}80 \%- \\
89 \%\end{array}$ & Baik & 12 & 27.3 \\
\hline $\begin{array}{c}65 \%- \\
79 \%\end{array}$ & Sedang & 27 & 61.4 \\
\hline $\begin{array}{c}55 \%- \\
64 \%\end{array}$ & Kurang & 2 & 4.5 \\
\hline $0 \%-54 \%$ & $\begin{array}{c}\text { Kurang } \\
\text { Sekali }\end{array}$ & 3 & 6.8 \\
\hline Jumlah & & 44 & 100 \\
\hline
\end{tabular}

Tabel 3 menunjukkan bahwa distribusi frekuensi keaslian dalam melakukan make up karakter dari 44 orang sampel ditemukan sebanyak 12 orang (27.3\%) mahasiswa berada pada kategori baik, 27 orang $(61.4 \%)$ mahasiswa berada pada kategori sedang, 2 orang (4.5\%) mahasiswa berada pada kategori kurang dan 3 orang (6.8\%) mahasiswa berada pada kategori kurang sekali.

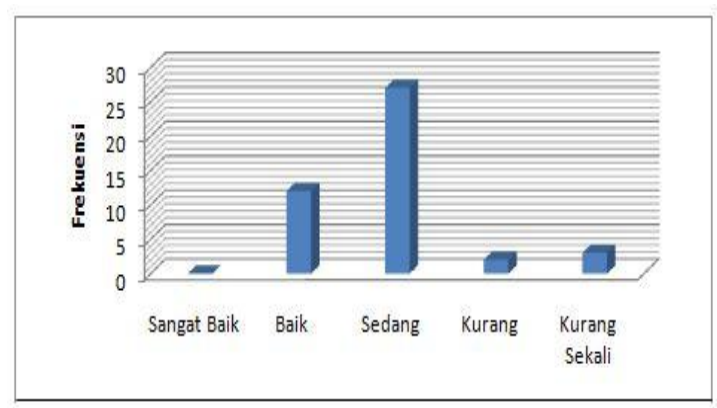

Gambar 3: Grafik Pribadi Kreatif Mahasiswa Yang Dilihat Dari Originality Pada Pembelajaran Make Up Karakter

B. Pembahasan

1. Pribadi Kreatif Mahasiswa Yang Dilihat Dari Fluency Pada Pembelajaran Make Up Karakter

Hasil penelitian menunjukkan bahwa distribusi frekuensi kelancaran dalam melakukan make up karakter dari 44 orang sampel ditemukan sebanyak 9 orang $(20.5 \%)$ mahasiswa berada pada kategori baik, 26 orang (59.1\%) mahasiswa berada pada kategori sedang, 6 orang (13.6\%) mahasiswa berada pada kategori kurang dan 3 orang $(6.8 \%)$ mahasiswa berada pada kategori kurang sekali.

Terlihat pada penelitian bahwa banyak mahasiswa mempunyai tingkat pribadi kreatif yang dilihat dari kelancaran pada kategori sedang dalam menciptakan make up karakter. Hal ini menunjukkan bahwa kemampuan mahasiswa untuk membangkitkan sebagian besar ide-ide dalam hal desain, warna, pakaian dan ornamen dengan mudah masih pada kategori sedang. Kelancaran berkaitan dengan kemampuan untuk membangkitkan sebagian besar 
ide-ide dengan mudah. "Kelancaran dibatasi tiga tipe yaitu: a) kelancaran ideasional; b) kelancaran asosional; c) kelancaran ekspresional". (Guilford dalam Evans, 1994:51). Kelancaran ideasional yaitu kecepatan membangun ide-ide berdasarkan pada kuantitas, kelancaran asosional yaitu menyelesaikan keterkaitan ataupun hubungan, dapat juga diterapkan dalam mengkonstruksi analogi, sedangkan kelancaran ekspresional yaitu kemampuan untuk mengkonstruksi kalimat. Dalam menciptakan suatu make up karakter diperlukan kelancaran, salah satunya dapat dilihat dengan kelancaran ideasional yaitu dengan kecepatan mahasiswa dalam membangun ide - ide tentang desain apa yang akan diciptakan, warna apa yang akan diaplikasikan, pakaian apayang akan digunakan dan juga ornamen apa yang akan mendukung karakter menjadi lebih sempurna.

Menurut Solso Dkk. (2008:444), "Kreativitas adalah suatu aktivitas kognitif yang menghasilkan suatu pandangan yang baru mengenai suatu bentuk permasalahan dan tidak dibatasi pada hasil yang pragmatis (selalu dipandang menurut kegunaannya)". "Kreativitas adalah keterampilan untuk menentukan pertalian baru, melihat subjek dari perspektif baru, dan membentuk kombinasi-kombinasi baru dari dua atau lebih konsep yang telah tercetak dalam pikiran", (Evans, 1994:1). Maksud dari kreativitas secara keseluruhan adalah untuk mengubah gagasan-gagasan atau menghasilkan tambahan gagasan-gagasan baru, (Edward, 1989:26).

Mahasiswa sebagai seorang pribadi yang kreatif, dituntut untuk lebih sigap dan lancar untuk menghasilkan banyak gagasan secara cepat. Sigap dan lancar menciptakan ide-ide tentang desain, warna, pakaian, dan ornamen yang akan digunakan untuk menciptakan sebuah make up karakter. Kelancaran dalam menciptakan karakter yang ingin dibuat sesuai tema. Didukung oleh pendapat

Olson Robert (1992:11) yang menyatakan bahwa "Kefasihan ditunjukan oleh kemampuan menghasilkan sejumlah besar gagasan pemecahan masalah secara lancar dan tepat".

Berdasarkan analisa peneliti terhadap hasil penelitian, Kondisi ini harus lebih ditingkatkan karena sebagai seorang pribadi yang kreatif, seorang mahasiswa dituntut untuk lebih sigap dan lancar dalam menuangkan ide dalam membuat make up karakter. Dalam hal ini banyak latihan bagi mahasiswa dalam membuat make up karakter sehingga tingkat kelancaran (fluency) mahasiswa bisa meningkat menjadi lebih baik.

2. Pribadi Kreatif Mahasiswa Yang Dilihat Dari Flexibility Pada Pembelajaran Make Up Karakter

Hasil penelitian menunjukkan bahwa distribusi frekuensi keluwesan dalam melakukan make up karakter dari 44 orang sampel ditemukan sebanyak 3 orang $(6.8 \%)$ mahasiswa berada pada kategori sangat baik, 18 orang $(40.9 \%)$ mahasiswa berada pada kategori baik, 20 orang $(45.5 \%)$ mahasiswa berada pada kategori sedang dan 3 orang $(6.8 \%)$ mahasiswa berada pada kategori kurang.

Fleksibilitas merujuk kepada kemampuan untuk membangkitkan banyak ide-ide, secara tidak langsung menunjukan kemudahan mendapatkan informasi tertentu atau berkurangnya kepastian dan kakakuan.

Terlihat pada penelitian bahwa banyak mahasiswa mempunyai tingkat pribadi kreatif yang dilihat dari keluwesan dalam pembelajaran make up karakter pada kategori sedang. Hal ini di tunjukan oleh kemampuan mahasiswa untuk menggunakan bermacam-macam cara dalam mengatasi masalah dalam menciptakan make up karakter, kemampuan untuk memproduksi sejumlah ide yang berhubungan dengan 
make up karakter, jawaban-jawaban atau pertanyaan-pertanyaan yang bervariasi, dapat melihat suatu masalah dari sudut pandang yang berbeda, mencari alternatif atau arah yang berbeda-beda dari mahasiswa lain, serta mampu menggunakan bermacam-macam pendekatan atau cara pemikiran yang berhubungan dengan make up karakter dalam hal desain, warna, pakaian, dan ornamen yang digunakan untuk menyempurnakan karakter yang ingin di munculkan. Mahasiswa dikatakan kreatif adalah apabila mahasiswa bisa berpikir secara luwes.

Menurut pendapat Olson Robert (1992:11), "Keluwesan pada umumnya mengacu pada kemampuan untuk menemukan gagasan yang berbeda-beda dan luar biasa untuk memecahkan suatu masalah".

Berdasarkan analisa peneliti terhadap hasil penelitian, Kondisi ini harus lebih ditingkatkan karena sebagai seorang pribadi yang kreatif, seorang mahasiswa dituntut untuk lebih mampu untuk memunculkan ide- ide alternatif yang tentunya sangat diperlukan dalam menciptakan make up karakter yang sesuai dengan tokoh atau karakter yang ditirukan. Mahasiswa diharapkan lebih fleksibel dalam menghadapi masalahmaslah dalam make up karakter. Dalam hal ini mencari sumber demo make up yang bervariasi, latihan, dan tidak monoton pada arahan dosen tentu sangat perlu bagi mahasiswa dalam membuat make up karakter sehingga tingkat keluwesan (flexibility) mahasiswa bisa meningkat menjadi lebih baik.

3. Pribadi Kreatif Mahasiswa Yang Dilihat Dari Originality Pada Pembelajaran Make Up Karakter.

Hasil penelitian menunjukkan bahwa distribusi frekuensi keaslian dalam melakukan make up karakter dari 44 orang sampel ditemukan sebanyak 12 orang $(27.3 \%)$ mahasiswa berada pada kategori baik, 27 orang (61.4\%) mahasiswa berada pada kategori sedang, 2 orang $(4.5 \%)$ mahasiswa berada pada kategori kurang dan 3 orang $(6.8 \%)$ mahasiswa berada pada kategori kurang sekali.

Terlihat pada penelitian bahwa banyak mahasiswa mempunyai tingkat pribadi kreatif yang dilihat dari keaslian, pada kategori sedang dalam hal menciptakan make up karakter. Hal ini menunjukkan bahwa kemampuan mahasiswa untuk mencetuskan gagasan unik atau asli pada kategori rata-rata, tentu dilihat pada segi desain, warna, pakaian, dan ornamen yang menjadi indikator dalam make up karakter. Menurut Evans (1994:53), "keaslian merupakan kemampuan untuk menghasilkan ide-ide luar biasa, memecahkan problem dalam cara luar biasa atau menggunakan hal-hal atau situasi dalam cara yang luar biasa". Dalam hal itu bisa diartikan sebagai memunculkan ide-ide baru, baru juga bisa diartikan berbeda dengan yang lain atau unik jika dilihat dari originality. Keaslian juga terkait dengan seberapa jarang suatu ide dihasilkan.

Berdasarkan analisa peneliti terhadap hasil penelitian, Kondisi ini menggambarkan kemampuan mahasiswa dalam menuangkan ide mereka sendiri dalam membuat make up karakter masih dikatakan kurang ataupun rata-rata. Mahasiswa belum terlalu mampu menampilkan bentuk make up karakter sesuai dengan ide yang mereka hasilkan sendiri. Hal ini harus ditingkatkan lagi menjadi lebih baik sehingga dapat meningkatkan kreatifitas mahasiswa dalam menuangkan ide mereka dalam melakukan make up karakter. Dalam hal ini banyak latihan, banyak mencari demo-demo make up karakter baru, karena pada masa sekarang sudah banyak terdapat tempat untuk mencari inspirasi seperti google dan youtube, bagi mahasiswa dalam membuat make up karakter sehingga tingkat pribadi kreatif 
yang dilihat dari keaslian (flexibility) mahasiswa bisa meningkat menjadi lebih baik.

\section{PENUTUP}

\section{Simpulan}

Berdasarkan hasil penelitian tentang tinjauan kreativitas mahasiswa pada mata kuliah tata rias foto/tv/film dan karakter di jurusan tata rias dan kecantikan maka dapat disimpulkan bahwa :

1. Rata-rata Kelancaran (Fluency) mahasiswa pada pembelajaran Make Up Karakter adalah 49.38 dengan kategori paling banyak adalah pada kategori sedang yaitu sebanyak 26 orang $(59.1 \%)$.

2. Rata-rata Keluwesan (Flexibility) mahasiswa pada pembelajaran Make Up Karakter adalah 47.02 dengan kategori paling banyak adalah pada kategori sedang yaitu sebanyak 20 orang $(45.5 \%)$.

3. Rata-rata Keaslian (Originality)) mahasiswa pada pembelajaran Make Up Karakter adalah 46.11 dengan kategori paling banyak adalah pada kategori baik yaitu sebanyak 20 orang (45.5\%).

\section{Saran}

1. Kepada Pihak Jurusan.

Kepada Prodi Pendidikan Tata Rias dan Kecantikan Fakultas Pariwisata dan Perhotelan, hasil penelitian ini dapat menjadi masukan dan referensi bahan perkuliahan untuk lebih menumbuhkan kreativitas yang dilihat dari pribadi kreatif mahasiswa dalam menuangkan ide mereka dalam membuat make up karakter berupa desain, warna, pakaian, dan ornamen.

2. Staf Pengajar.

Agar selalu berupaya mencari strategi yang tepat pada proses pembelajaran, yang dapat meningkatkan kreativitas mahasiswa pada pembelajaran make up karakter.

3. Kepada Mahasiwa.

Kepada mahasiswa disarankan untuk lebih sering lagi berlatih membuat make up karakter dan lebih berani menuangkan ide sendiri sesuai dengan situasi dan kondisi yang diharapkan sehinnga melahirkan idea tau gagasa yang lebih kreatif lagi dalam membuat make up karakter.

4. Kepada peneliti.

Selain syarat menyelesaikan pendidikan juga merupakan kesempatan untuk mencoba dan berlatih langsung melakukan pengkajian kreatifitas mahasiswa dalam membuat make up karakter dan menerapkan ilmu-ilmu yang diperoleh dari perkuliahan.

5. Peneliti lainnya.

Sebagai bahan referensi untuk melakukan penelitian lain tentang kreativitas kebagian produk kreatif.

\section{DAFTAR PUSTAKA}

Alhekmah. 2014. "Peningkatan Keterampilan Marias Wajah Karakter Melalui Pelatihan Bagi Siswa Kelas XI Tata Kecantikan Rambut SMK Negeri 1 Lamongan”. Edisi Yudisium. 3 (1) : 271-276.

Evans, James R. 1994. Berpikir Kreatif dalam Pengambilan Keputusan dan Manajemen. Jakarta: Bumi Aksara.

Irnis Uchi.2018.'”kreativitas mahasiswa pada mata kuliah menghias busana di jurusan kesejahteraan keluarga fakultas pariwisata dan perhotelan universitas negeri padang". Skripsi. FPP UNP Padang.

Mitra lusiana.2013."kreativitas Pada Mata Kuliah Tata Rias Panggung Prodi Tata Rias dan Kecantikan Jurusan Kesejahteraan Keluarga Fakultas Teknik Universitas Negeri Padang”. Tesis. Program Pasca Sarjana UNP Padang.

Munandar Utami. 1992. Mengembangkan Bakat dan Kreativitas Anak Sekolah. Jakarta: PT. Gramedia Widiasarana.

2009. Pengembangan Kreativitas Anak Berbakat. Jakarta: Rineka Cipta. . 2004. Pengembangan Emosi dan Kreativitas. Jakarta: Rineka Cipta.

Olson, Robert W. 1992. The Art Of Creative Thinking A Practical Guide : Seni Berpikir Kreatif Sebuah Pedoman Praktis. Jakarta: Erlangga.

Paningkiran Halim. 2013. Make Up Karakter Untuk Televisi \& Film. Jakarta: PT Gramedia Pustaka Utama.

Solso, Robert L.dkk. 2008. Psikologi Kognitif. Jakarta: Erlangga. 
Sudarma Momon. 2013. Mengembangkan Keterampilan Berpikir Kreatif. Jakarta: Rajawali Pers.

Thowok, Didik Nini. 2012. Stage Make Up. Jakarta: PT Gramedia Pustaka Utama.

Vangundi, Artur B. 2011. Cara mendapatkan IdeIde Kreatif dan Cemerlang. Jakarta: PT. Indeks.

Yuliati, Nanie Asri. 2007. "Peningkatan Kreativitas Seni Dalam Desain Busana". 5 (2) : 173-184. 